\title{
PENGARUH STRUKTUR KEPEMILIKAN, KEBIJAKAN HUTANG DAN CORPORATE SOCIAL RESPONSIBILITY TERHADAP KEBIJAKAN DIVIDEN
}

\author{
Sherrin Tjandra ${ }^{1)^{*}}$, Santi Yopie ${ }^{2}$ \\ ${ }^{1}$ Fakultas Ekonomi, Universitas Internasional Batam \\ email: sherrintjandra@yahoo.com \\ ${ }^{2}$ Fakultas Ekonomi, Universitas Internasional Batam \\ email: santiyopie.uib@yahoo.com
}

\begin{abstract}
This study intends to carry out data testing on the influence of ownership structure, debt policy, corporate social responsibility on dividend policy. The ownership structure used in this study is managerial and institutional ownership. This study takes secondary data in the form of annual reports of a public entity or public company that is processed from the Indonesia Stock Exchange (IDX). The time range for data collection is 2014-2018. The procedure in selecting and taking samples is applying the purposive sampling method and the process of testing and analyzing data. The results of testing the data prove that the ownership of a manager and institute along with a debt policy is positively significant in dividend policy. High managerial ownership will make managerial parties behave opportunistically to increase dividend payments, ownership of the institute will be under strict supervision so that management must follow the wishes of shareholders. The higher the debt will result in income received must be set aside for debt repayment. Corporate social responsibility does not have a significant effect on dividend policy because the increase in disclosure or decrease has no effect on dividend policy.
\end{abstract}

Keywords: managerial ownership, institutional ownership, debt policy, corporate social responsibility, dividend policy.

\section{ABSTRAK}

Studi ini bermaksud melaksanakan pengujian data pengaruh struktur kepemilikan, kebijakan hutang, corporate social responsibility terhadap kebijakan dividen. Struktur kepemilikan yang dipilih untuk digunakan pada studi ini yakni adalah kepemilikan manajerial dan institusional. Studi ini mengambil data sekunder berbentuk laporan tahunan sebuah entitas public atau perusahaan public yang diolah dari Bursa Efek Indonesia (BEI). Rentang waktu pengambilan data adalah 2014-2018. Prosedur dalam pemilihan dan pengambilan sampel yakni menerapkan metode purposive sampling dan proses pengujian serta analisis data. Hasil pengujian data membuktikan bahwa kepemilikan seorang manajer dan institut beserta kebijakan hutang bersignifikan positif pada kebijakan dividen. Kepemilikan manajerial tinggi akan membuat pihak manajerial berperilaku oportunistik untuk meninggikan pembayaran dividen, kepemilikan institusional akan berada dibawah pengawasan yang ketat sehingga pihak manajemen harus mengikuti kemauan pemegang saham. Semakin tinggi hutang akan mengakibatkan pendapatan yang diterima harus disisihkan untuk pelunasan hutang. Corporate social responsibility tidak ditemukan adanya pengaruh yang signifikan pada kebijakan dividen dikarenakan kenaikan pengungkapan maupun penurunan tidak ada pengaruh terhadap kebijakan dividen.

Kata kunci: kepemilikan manajerial, kepemilikan institusional, kebijakan hutang, corporate social responsibility, kebijakan dividen 


\section{PENDAHULUAN}

Pendirian perseroan tentu tidak luput dengan keinginan mencapai keuntungan maksimal adapun perusahaan memiliki tujuan untuk memakmurkan pemilik perusahaan dan juga pemilik saham (Sukarsih, 2018). Seluruh pendapatan dari kegiatan perusahaan terkadang belum bisa membiayai seluruh pengeluaran mereka maka dari itu dibutuhkan pihak eksternal yaitu para pemilik saham atau investor. Pihak eksternal ini menanamkan dana meraka pada suatu perusahaan dengan harapan mendapat feedback yaitu pengembalian berupa dividen.

Menurut Nuraina (2018), setiap perusahaan tentu ingin selalu berkembang dan tumbuh dan juga membayar kewajibannya kepada para pemilik saham tetapi kedua tujuan tersebut tidak dapat disatukan dikarenakan apabila pembayaran dividen meningkat maka pendapatan perusahaan akan berkurang sehingga laba ditahan juga berkurang yang menghambat pertumbuhan perusahaan. Sebaliknya apabila tidak dilakukan pembagian dividen maka laba ditahan akan bertambah guna dalam pembiayaan operasional maupun aktifitas perusahaan di masa yang akan datang.

Proporsi kepemilikan saham yang dikendalikan baik dari pihak institusional maupun dari pihak manajerial dapat mempengaruhi kebijakan dividen (Putri, 2015). Pemegang saham institusi menginginkan supaya laba atau keuntungan maksimal yang dihasilkan perusahaan dapat digunakan atau diinvestasikan ke dalam perusahaan sehingga akan berpengaruh terhadap kebijakan dividen.

$$
\text { Menurut Fardiana (2018), }
$$

Corporate Social Responsibility merupakan etika bisnis dimana perusahaan harus bertanggung jawab atas kerusakan maupun kesenjangan sosial akibat aktivitas operasional. Pelaksanaan CSR secara konsisten dapat memberi image perusahaan yang bagus dan citra perusahaan akan meningkat yang akan mempengaruhi penjualan perusahaan ke arah yang lebih baik dikarenakan investor cenderung lebih memilih perusahaan yang melakukan kegiatan CSR. Kebijakan hutang adalah keputusan perusahaan untuk pengambilan hutang sebagai pembiayaan apabila hutang tinggi maka menurunkan kemampuan perusahaan dalam membagikan dividen mereka sebab sebagian dana akan dialokasikan untuk kepentingan pelunasan hutang (Sofia, 2016).

Penelitian yang berkaitan dengan topik ini banyak sekali diteliti sebelumnya dan menghasilkan hasil yang bervariasi. Penelitian kali ini yakni merupakan gabungan dari 2 (dua) penelitian terdahulu yang dilaksanakan oleh Maristi (2016) dan Nurwani (2016), adapun perbedaan penelitian yaitu penambahan 2 (dua) variabel yakni kebijakan hutang dan corporate social responsibility serta menggunakan sampel dari website Bursa Efek Indonesia (BEI) aktif tahun 20142018.

Dengan diuraikannya konteks tertera di atas maka termotivasi untuk dilakukannya sebuah studi berjudul "Pengaruh Struktur Kepemilikan, Kebijakan Hutang dan Corporate Social Responsibility terhadap Kebijakan Dividen".

\section{KERANGKA TEORITIS DAN PERUMUSAN HIPOTESIS}

\section{Kebijakan Dividen}

Variabel dependen biasanya juga disebut sebagai variabel terikat kadang juga disebut sebagai variabel kriteria serta konsukuen. Variabel dependen memiliki arti yang dinyatakan oleh Sugiyono (2016) sebagai sebuah variabel yang dipengaruhi atau menjadi sebuah akibat dikarenakan adanya variabel bebas atau dalam kata lain adalah variabel independen. Variabel dependen juga dapat didefinisikan sebagai variabel yang dijelaskan atau dipengaruhi 
oleh variabel independen. Variabel dependen disebut juga variabel yang diduga sebagai akibat (presumed effect variable). Variabel dependen juga dapat disebut sebagai variabel konsekuensi (Lie, 2009). Maka pada penelitian ini dipilihnya variabel dependen yaitu kebijakan dividen.

Sugiarto (2015) berpendapat bahwa dividen dibayarkan atau tidak tergantung kebijakan dividen yang di ambil. Apabila dibagikan maka profit setiap akhir tahun akan disisihkan untuk pembayaran dividen atau ditahan sebagai retained earnings. Ini mengacu pada praktik manajemen perusahaan dalam mengambil keputusan pembagian dividen baik dari segi ukuran serta pola distribusi kas (Sarih, 2017). Pemegang saham pada umumnya mempercayai sinyal yang diberikan dalam membagikan dividen memberikan gambar mengenai kemampuan sebuah perusahaan untuk menghasilkan laba (Aydin \& Cavdar, 2015).

Perusahaan yang memutuskan untuk menyisihkan keuntungan menjadi dividen maka menurunkan retained earnings sehingga berkurangnya dana yang digunakan untuk intern dalam pengembangan usaha. Sebaliknya jika sebagian pendapatan tersebut dijadikan sebagai modal masa mendatang maka dapat menyokong pengembangan perusahaan kedepannya (Ita, 2017). Kebijakan dividen ini memiliki peran yang sangat penting dikarenakan pembagian dividen ini akan berpengaruh terhadap laba ditahan yang biasa merupakan dana internal terpenting bagi pertumbuhan dan pengembangan usaha serta pembiayaan operasional di masa depan (Rais \& Santoso, 2017). Kebijakan dividen dapat dihitung dengan memperhitungkan rasio dari pembayaran dividen yang dimana merupakan bagian dari total pendapatan usaha yang telah dibagikan dalam bentuk dividen (Noviana, 2017).

\section{Model Penelitian Terdahulu}

Penelitian dengan menggunakan variabel dependen sebelumnya telah banyak dilakukan contohnya seperti penelitian yang dilakukan oleh Damayanti dan Marwati (2017) dan Amalia dan Kartina (2017) mengenai faktor-faktor yang dapat mempengaruhi kebijakan dividen pada perusahaan. Dewi dan Rusliati (2017) juga meneliti hal yang serupa dengan menambahkan variabel independen yakni struktur kepemilikan dan ukuran perusahaan. Penelitian serupa juga dilaksanakan oleh Rais dan Santoso (2017) dengan menggunakan variabel kepemilikan manajerial, institusional dan ukuran perusahaan pada kebijakan dividen. Penelitian lainnya juga diteliti dengan menambahkan profitabilitas dengan kepemilikan manajerial, kebijakan hutang juga dilaksanakan oleh Isticharoh (2016) dan Nurwani (2018) juga meneliti mengenai pengaruh kepemilikan institusional, kepemilikan manajerial dan profitabilitas terhadap kebijakan dividen pada perusahaan sektor manufaktur. Penelitian mengenai kebijakan dividen juga dikembangkan oleh Bong (2017) dimana dilaksanakan penelitian mengenai faktorfaktor yang mempengaruhi kebijakan pembayaran dividen pada perusahaan yang terrcatat pada BEI.

Penelitian mengenai struktur kepemilikan terhadap kebijakan dividen perusahaan dilakukan oleh Wuisan, Randa dan Lukman (2018) Penelitian mengenai pengaruh kepemilikan institusional dan kebijakan dividen juga dilakukan oleh Sutanto, Marciano dan Ernawati (2017) dengan meneliti perusahaan sektor industri properti. Penelitian yang sama juga dilakukan oleh Wirdani (2019) dengan menggunakan variabel kepemilikan manajerial dan kepemilikan institusional terhadap kebijakan pembayaran dividen dengan menambahkan 1 (satu) variabel dependen yaitu kinerja perusahaan pada perusahaan yang terdaftar di BEI. Penelitian yang serupa juga dikembangkan oleh Affifah, Ratih, dan Husna (2018) dengan 
menggunakan variabel kepemilikan manajerial, kepemilikan institusional, kebijakan hutang dan ukuran perusahaan pada kebijakan dividen dengan meneliti sampel perusahaan manufaktur yang terdaftar di BEI. Penelitian yang sama juga dilaksanakan oleh Dewi dan Rusliati (2017) yang meneliti mengenai pengaruh kepemilikan manajerial, institusional dan ukuran perusahaan terhadap kebijakan pembayaran dividen. Penelitian yang sama kemudian dikembangkan yang dilaksanakan oleh Fimanda, Raharjo, dan Oemar (2015) dengan variabel yang sama yaitu kepemilikan manajerial, kepemilikan institusional, kebijakan hutang, profitabilitas dan ukuran perusahaan dengan menambahkan 1 (satu) variabel independen yaitu cash position pada keijakan pembayaran dividen.

\section{Pengaruh Kepemilikan Manajerial terhadap Kebijakan Dividen}

Kepemilikan manajerial memiliki arti sebagai kepemilikan dari seorang manajer atas saham pada perusahaan atau dalam kata lain manajer perusahaan tersebut adalah dan juga sebagai pemegang saham perusahaan (Indriani, 2015). Kepemilikan manajerial tinggi dapat menyebabkan dividen payout menjadi sedikit dikarenakan manajer selalu berharap investasi di periode seterusnya akan ditutup dari sumber internal. Pribadi (2012) berpendapat bahwa apabila manajer pada suatu perusahaan memiliki proporsi saham yang kecil maka perusahaan cenderung membagikan hak pemegang saham secara rendah dan sebaliknya jika pembayaran dividen menurun diakibatkan oleh tingginya kepemilikan saham oleh manajer dalam suatu perseroan.

Analisis yang dilakukan oleh Nuringsih (2005) menyatakan bahwa adanya keterlibatan seorang manajer dalam kepemilikin manajerial maka akan menyebabkan asset yang dimiliki tidak optimal dan manajer berharap dividen yang cenderung lebih besar. Penelitian serupa juga dilakukan oleh Rais (2017) dan Devi (2014) dimana pada kedua penelitian ditemukan hasil dimana kepemilikan pihak manajerial tidak ditemukan adanya pengaruh yang signifikan pada kebijakan dividen pada sebuah perusahaan. Hal ini akan tetapi bertentangan dengan hasil penelitian yang dilaksanakan oleh Fauzi dan Mursallam (2015), Indriani (2015), Yulianto (2011) dan Wirdani (2019) yang hasil penelitian menyatakan tidak adanya pengaruh antara kedua variabel.

\section{Pengaruh Kepemilikan Institusional terhadap Kebijakan Dividen}

Dalam terminologi Bursa Saham, kepemilikan institusional didefinisikan sebagai saham yang dimiliki oleh lembaha keuangan diluar dari bank contohnya seperti lembaga reksa dana, dana pension, asuransi dan investasi. Hanafi (2005) berpendapat bahwa tingginya pemilik saham institusional maka semakin tinggi pengawasan dari luar dan juga mengurangi agency cost. Kesamaan hasil oleh Nasir (2008) dimana disebutkan bahwa naiknya kepemilikan oleh institutional maka berkurangnya kos agen dan perusahaan akan membagikan cenderung rendah. Hasil penelitian yang dilaksanakan oleh Kurniawati et al., (2015), (Nisa, 2016) dan Sutanto, Marciano, \& Ernawati (2017) menemukan bahwa pada variabel kepemilikan institusional menuaikan hasil bahwa adanya pengaruh pada kebijakan dividen sebuah perusahaan. Hal ini akan tetapi bertolak belakang pada penelitian yang dilaksanakan oleh Dewi (2012), Wikansari (2015) dan Jayanti \& Puspitasari (2019) yang menerima hasil bahwa tidak adanya pengaruh bersignifikan pada kebijakan dividen.

\section{Pengaruh Kebijakan Hutang terhadap Kebijakan Dividen}

Kebijakan hutang pada dasarnya merupakan keputusan peminjaman dana sebagai pendanaan kegiatan operasional perusahaan dari pihak ketiga. 
Pendayagunaan hutang tinggi dapat mengakibatkan penurunan dividen dikarenakan pendapatan yang telah diterima akan disisihkan dan digunakan kembali sebagai pelunasan hutang kepada pihak ketiga (Saerang, 2015). Sebaliknya apabila penggunaan hutang rendah maka keuntungan yang di dapatkan dapat dialokasikan untuk kesejahteraan para pemegang saham dengan membagikan kewajiban mereka kepada pemegang saham yakni dividen pada para pemegang saham. Beberapa penelitian lain seperti penelitian yang dilaksanakan oleh Indahningrum dan Ratih (2009), Isticharoh (2016), Thaib \& Taroreh (2015) yang menyatakan bahwa ditemukan ada pengaruh antara kebijakan hutang dengan kebijakan dividen. Hal ini bertentangan dengan penelitian yang dilaksanakan oleh Setiawati \& Yesisca (2016) , Sulis (2018) yang mendapatkan kesimpulan bahwa kedua variabel tersebut tidak memiliki signfikansi apapun

\section{Pengaruh Corporate Social Responsibility terhadap Kebijakan Dividen}

Organisasi dengan nama The World Business Council For Sustainable Development atau disingkat sebagai WBCSD menyatakan CSR adalah tanggung jawab yang wajib dilakukan oleh seluruh badan usaha sebagai pertanggung jawaban mereka dalam meningkatkan kualitas hidup dan mencegah kerusakan yang terjadi akibat kegiatan perusahaan. Dengan melakukan CSR maka nama perusahaan akan membaik di kalangan masyarakat ini juga mempengaruhi minat investor. Kebanyakan investor cenderung berminat berinvestasi kepada entitas yang melaksanakan dan mengungkapkan informasi kegiatan CSR. Hasil pada penelitian ini terdukung dengan hasil penelitian yang telah dilaksanakan oleh Ira (2014) dan Titi (2014) yang menuai hasil bahwa tidak adanya pengaruh antara $C S R$ pada kebijakan dividen tetapi kesimpulan yang diberikan tidak serupa seperti hasil yang ditemukan pada penelitian yang dilaksanakan oleh Armi (2016) yang menghasilkan kesimpulan adanya pengaruh signifikan antar kedua variabel tersebut.

\section{Pengaruh Ukuran Perusahaan terhadap Kebijakan Dividen}

Perseroan besar cenderung lebih stabil dan memiliki jalan masuk efisien ke dalam pasar modal. Hal ini dapat meningkatkan dependensi sebuah perusahaan terhadap pembiayaan internal, hingga perusahaan dapat membayar dividen tinggi. Argumen didukung penelitian Hatta (2002) dan Nuringsih (2005), di mana kesimpulan yang ditarik dari analisis adalah bahwa perusahaan dengan aset tinggi memberikan dividen besar pada pemegang saham demi reputasi perusahaan mereka di antara investor.

\section{METODE PENELITIAN}

Studi ini memiliki beberapa aspek, apabila di lihat dari sumber penerimaan data maka studi ini mengolah, menerima dan menggunakan data yang sekunder, dimana arti dari data sekunder yakni merupakan sekumpulan data yang telah dikumpulkan oleh lembaga yang bertugas mengumpulkan data kemudian akan dipublikasi untuk digunakan oleh semua masyarakat pengguna data (Ira, 2018). Data yang digunakan juga berjenis sebagai sebuah penelitian arsip. Penelitian arsip yang dimaksud adalah pengambilan data berupa fakta tertulis dalam bentuk dokumen atau merupakan arsip data (Sudianto, 2019).

Penelitian ini mengolah data crosssectional dan time series. Cross sectional merupakan hubungan komparatif dengan membandingkan rasio-rasio antar perusahaan di waktu yang besamaan. Alasan penggunaan ini karena seeluruh variabel akan diukur secara simultan di saat yang sama kemudian time series adalah perbandingan antar beberapa perusahaan dari satu periode ke periode berikutnya (Amri, 2019). Analisa ini bertujuan untuk mendapatkan proyeksi perkembangan 
perusahaan di masa selanjutnya melalui rentang waktu yang telah berlalu.

Variabel yang akan diteliti memiliki sifat kuantitatif atau merupakan data yang dapat diukur secara langsung melalui angka atau bilangan (Siswandari, 2017). Data yang telah dikumpulkan akan diolah dengan proses statistika yaitu pengolah menggunakan SPSS untuk mendapatkan hasil uji statistik deskriptif dan Eviews 10 untuk melakukan uji regresi data panel. Objek pada penelitian merupakan data-data perusahaan sebelumnya yang dinamakan sebagai penelitian historis (Indriantoro \& Supomo, 2009).

\section{Objek Penelitian}

Penelitian ini dilaksanakan dengan tujuan ingin mengetahui pengaruh dari variabel kepemilikan manajerial, kepemilikan institusional, kebijakan hutang dan tanggung jawab sosial terhadap kebijakan dividen. Variabel independen pada penelitian ini yakni adalah kepemilikan institusional, kepemilikan manajerial, kebijakan hutang dan CSR serta variabel independen yang digunakan adalah kebijakan dividen.

Objek yang terpilih pada penelitian ini adalah seluruh perusahaan yang aktif terdaftar pada BEI sejak 2014-2018. Ada 629 perusahaan yang terdaftar pada periode tersebut dan digunakan metode purposive sampling yaitu metode pemilihan sesuai dengan syarat dan pertimbangan. Sampel memiliki kriteria agar dapat dijadikan data penelitian sebagai berikut:

1. Entitas perseroan tercatat wajib memiliki data laporan keuangan sebanyak 5 tahun beruntun dan adanya pembayaran dividen pada tahun 2014-2018.

2. Laporan keuangan berbasis rupiah serta memiliki data variabel-variabel yang akan diteliti

\section{Variabel Dependen}

Kategori penggunaan variabel dependen dan independen sering terlihat dan paling sering digunakan pada proses penjelasan dan prediksi sebuah fenomena dalam proses pengujian data. Dependen akan dijelaskan oleh independen yang diteliti yakni kepemilikan institusional, manajerial, kebijakan hutang serta ukuran suatu perseoraan dimana variabel dependen yang dipilih merupakan Kebijakan Dividen.

Pemegang saham biasanya dapat menerima sinyal apakah perusahaan dalam keadaan baik atau buruk dengan melihat kebijakan dividen yang berpengaruh akan harga saham perusahaan (Aisyah, 2016). Seperti yang telah dijabarkan diatas pengertian inti kebijakan dividen merupakan cerminan dari kemampuan sebuah perusahaan atau entitas dalam memenuhi kewajiban mereka kepada pemilik saham suatu perusahaan atau entitas. Dividen yang terbayar akan berpengaruh pada harga saham juga mempengaruhi kepentingan para pemegang saham (Munawar, 2018).

Kebijakan dividen merupakan data yang diambil dari berbagai sumber dan tidak langsung diterima dari pemberi data hal ini disebut sebagai data sekunder. Data yang diperoleh bersifat kuantitatif karena wujud dari data merupakan angka atau bilangan dengan skala pengukuran yaitu data rasio yakni data yang diterima memiliki jarak dua titik yang tekah diketahui (Indra, 2013). Data kuantitatif merupakan bahan dasar setiap permasalahan yang bersifat statistik (Siyoto \& Sodiq, 2015). Menurut Setia (2016) rumus perhitungan dividen adalah:

\begin{tabular}{|c|c|c|}
\hline & & $\begin{array}{c}\text { Dividend Per } \\
\text { Share }\end{array}$ \\
\hline $\begin{array}{c}\text { Payout } \\
\text { Ratio }\end{array}$ & $=$ & $\begin{array}{l}\text { Earning Per } \\
\text { Share }\end{array}$ \\
\hline
\end{tabular}

\section{Kepemilikan Manajerial}

Kepemilikan manajerial seperti
namanya merupakan angka dari kepemilikan saham seorang manajer dari angka modal kepemilikan modal saham yang dimiliki sebuah perusahaan. Pihak manajer juga memiliki peran aktif pada saat 
pengambilan keputusan dalam penentuan keberlangsungan entitas atau perseroan (Gideon, 2005). Seorang manajer memiliki wewenang dan kesempatan untuk terlibat dengan tujuan untuk menyetarakan kepentingan mereka sebagai salah satu pemegang saham pada sebuah perusahaan (Pujiati, 2015). Keterlibatan seorang manajer akan membuat aset perusahaan tidak terdiversifikasi secara optimal dikarenakan adanya sifat oportunistik seorang manajer yang menginginkan pembayaran dividen yang lebih besar (Kartika, 2019)

Data kepemilikan manajerial merupakan data sekunder yang datanya telah diambil oleh lembaga pengambil data ke dalam bentuk laporan keuangan perusahaan dan merupakan data kuantitatif dimana data berbentuk angka atau bilangan dengan skala pengukuran sebagai data rasio dikarenakan adanya jarak dua titik skala yang telah diketahui (Indra, 2013). Pengukuran yang dapat digunakan dalam mencari angka kepemilikan pihak manajer yakni dengan cara memperhitungkan rasio antara jumlah saham manajer dengan saham yang beredar dipasaran. Rumus perhitungan kepemilikan manajerial yang dikemukan oleh Masdupi (2012) adalah:

\begin{tabular}{|c|c|}
\hline $\begin{array}{c}\text { Manajerial } \\
\text { Ownership }\end{array}$ & $=\begin{array}{c}\text { Jumlah Kepemilikan } \\
\text { Manajerial }\end{array}$ \\
\cline { 2 - 3 } & $\begin{array}{c}\text { Jumlah Saham } \\
\text { Beredar }\end{array}$ \\
\hline
\end{tabular}

\section{Kepemilikan Institusional}

Kepemilikan manajerial didefinisikan sebagai kepemilikan dari pihak manajer maka kepemilikan institusional didefinisikan sebagai kepemilikan badan institut diluar dari perusahaan. Lembaga yang tergolong dalam kategori kepemilikan institusional contohnya adalah reksa dana, asuransi, dan usaha yang memberikan jasa investasi. Pengawasan efektif yang dilakukan akan memaksa manajemen untuk bertindak mengikuti wewenang para pemegang saham dimana pemegang saham institusional biasa menginginkan modal digunakan sebagai pembiayaan operasional perusahaan. Hal tersebut membuktikan bahwa tingginya kepemilikan institusional menunjukkan penurunan pembayaran dividen dikarenakan pendapatan yang diterima dialokasikan kembali menjadi laba ditahan (Pujiati, 2015).

\section{Pengukuran}

kepemilikan institusional tidak jauh dari rumus perhitungan kepemilikan manajerial dimana data yang diteliti juga bersifat sebagai data sekunder yang diolah dengan laporan yang telah ada serta data kepemilikan institusonal juga bersifat sebagai data kuantitaif dengan skala pengukuran sebagai data rasio (Siyoto \& Sodiq, 2015). Rasio perhitungan kepemilikan institusional yang dikemukan oleh Masdupi (2012) mencakup pembagian antara jumlah saham pemilik institut dengan jumlah saham yang beredar di pasar. Rumus dapat digambarkan menjadi:

\begin{tabular}{|c|c|}
\hline $\begin{array}{c}\text { Institusional } \\
\text { Ownership }\end{array}$ & $=\begin{array}{c}\text { Jumlah Kepemilikan } \\
\text { Institusional }\end{array}$ \\
\cline { 2 - 2 } & Jumlah Saham Beredar \\
\hline
\end{tabular}

\section{Kebijakan Hutang}

Hutang menurut FASB dalam SFAC no. 6 adalah sebuah manfaat ekonomi yang dikorbankan di masa yang akan datang dikarenakan timbul kewajiban sekarang dikarenakan adanya transaksi yang dilakukan di masa sebelumnya. Kebijakan hutang adalah tingkat hutang oleh suatu perusahaan yang diambil perusahaan dalam pembiayaan operasional perusahaan. Dalam suatu entitas biasanya hutang dianggap sebagai alternatif yang harus ditempuh untuk meminimalisir agency cost (Utami, 2017).

Demi memenuhi seluruh pendanaan perusahaan, ada dua kubu dimana pemegang saham memilih pendanaan tersebut ditutup dengan berhutang sedangkan manajemen tidak setuju akibat resiko yang timbul selama berhutang. Kebijakan hutang merupakan data sekunder 
yang dapat ditemukan pada laporan keuangan perusahaan yang telah diambil oleh lembaga pengambil data, dengan data yang bersifat kuantitatif dimana data yakni kumpulan angka dan bilangan serta skala pengukuran yang bersifat sebagai data rasio dimana data memiliki nilai 0 (nol) mutlak (Yusuf, 2014). Rasio perhitungan pada variabel ini menurut Brigham (2010) adalah dengan membagikan jumlah dari hutang sebuah perusahaan dengan jumlah ekuitas yang dimiliki yang digambarkan sebagai berikut:

\begin{tabular}{|l|l|l|}
\hline $\begin{array}{c}\text { Kebijakan } \\
\text { Hutang }\end{array}$ & & Total Hutang \\
& $=$ & Total Ekuitas \\
\hline
\end{tabular}

\section{Corporate Social Responsibility}

Corporate Social Responsibility (CSR) yang dilakukan sebuah entitas sebagai bukti bahwa mereka memiliki tanggung jawab serta adanya kepedulian perusahaan tersebut terhadap lingkungan sekitar. CSR juga merupakan sebuah program investasi jangka panjang dimana semakin banyak pertanggung jawaban sebuah perusahaan terhadap lingkungan maka image perusahaan juga akan membaik di mata masyarakat luas. Investor akan semakin berminat untuk menanamkan sahamnya pada perusahaan yang melakukan CSR secara rutin dikarenakan apabila sebuah perusahaan memiliki citra yang baik maka loyalitas konsumen cenderung meningkat sehingga penjualan perusahaan juga akan terus meningkat. Retno dan Pratinah (2012) juga berpendapat jika perusahaan berjalan lancer, maka nilai saham juga akan terus meningkat, pernyataan ini didukung oleh Febriyanti (2012), perusahaan diharapkan tidak hanya mementingkan mendapatkan keuntungan maksimal untuk perusahaan melainkan juga bertanggung jawab akan lingkungan sekitar dan masyarakat.

Cara mengukur Corporate Social Responsibility yaitu dengan menggunakan standar ISO 26000. Standar ini menerangkan bahwa adanya 34 item atau kriteria yang harus diungkapkan oleh perusahaan saat melakukan tanggung jawab sosial, item-item tersebut. Pencatatan data mengenai CSR membutuhkan proses yang panjang dikarenakan harus mencari apakah suatu item telah diungkapkan dalam laporan keuangan setiap perusahaan yang diteliti. Jika item diungkapkan oleh suatu perseroan pada laporan maka akan memberikan angka 1 (satu) apabila tidak terungkap maka dituliskan angka 0 (nol) yang berarti tidak diungkapkan oleh perusahaan tersebut. Dari angka tersebut maka jumlah item yang diungkapkan akan ditambahkan dengan item yang tidak diungkapkan hasil tersebut kemudian akan dibagi dengan 34 (tiga puluh empat) yang merupakan jumlah dari pengungkapan di dalam ISO 26000.

Indeks Kepatuhan $=\frac{\sum \mathrm{Xn}}{34}$

Keterangan:

$\sum \mathrm{Xn}=$ jumlah pengungkapan perusahaan

sampel pada setiap tema

$34=$ jumlah item pengungkapan dalam ISO 26000

\section{Ukuran Perusahaan}

Hidayat (2013) menyatakan bahwa besar kecil suatu perusahaan dapat diketahui dalam laporan keuangan dengan memperhatikan jumlah aset suatu perusahaan. Ukuran perusahaan juga mencerminkan secara langsung aktifitas operasional perusahaan. Intinya, semakin besar ukuran dari sebuah perusahaan maka dapat disimpulkan perusahaan tersebut memiliki tingkat aktifitas yang tinggi dan sebaliknya apabila ukuran perusahaan tersebut kecil maka disimpulkan aktifitas dalam perusahaan tersebut rendah (Pradhana et al., 2014). Menurut Hidayat (2011), ukuran perusahaan juga layaknya sebuah indikator bagi para investor dimana mereka dapat menilai ukuran sebuah perusahaan dari besar kepemilikan aset sebuah perusahaan. Ketika sebuah perusahaan mempunya aset besar maka kemungkinan perusahaan tersebut yakni 
adalah perusahaan berukuran besar dengan kinerja yang terus berkembang dan tingkat aktifitas operasional yang tinggi.

Perhitungan ukuran perusahaan sangat mudah dikarenakan hanya membutuhkan laporan keuangan suatu perusahaan kemudian melihat besar asset yang dimiliki oleh sebuah perusahaan. Badriyah (2017) berargumen bahwa setiap laporan keuangan tentu memiliki total aset sehingga hanya melihat nominal keseluruhan aset kepunyaan perseroan tersebut dapat diketahui ukuran perusahaan. Ukuran perusahaan dirincikan dalam persamaan sebagai berikut:

\section{SIZE $=$ LnTotal Asset}

\section{Teknik Pengumpulan Data}

Data dikumpulkan dan disalurkan melalui halaman website https://www.idx.co.id/ yang berisikan laporan tahunan perseroan aktif listing di BEI. Dimana angka-angka dari laporan tersebut akan diambil sesuai dengan data yang diperlukan dan diolah untuk penelitian.

Data yang diakumulasi dari laporan keuangan setiap perseroan merupakan data sekunder dikarenakan diperoleh pada sumber yang telah ada yaitu website BEI. Sampel pada riset ini adalah seluruh laporan perseroan mengenai keuangan yang telah menyelesaikan proses audit dan di upload ke website BEI selama 2014-2018 yang telah memenuhi syarat yang ditentukan

\section{Metode Analisis Data}

Perangkat lunak SPSS akan digunakan untuk menguji data sekunder dimana akan memperoleh hasil uji data statistik deskriptif. Metode yang digunakan adalah observasi tanpa partisipasi dikarenakan hanya melihat dari laporan keuangan perusahaan dalam pengumpulan data (Sugiyono, 2014).

Teknik regresi panel akan diimplementasikan untuk pengukuran relasi variabel satu dengan variabel lainnya.
Dimana pengimplementasian tersebut berfungsi agar mendapatkan jawaban apakah ada pengaruh pada variabel-variabel tersebut.

\section{Uji Statistik Deskriptif}

Percobaan olah data untuk menggambarkan serta memberi deskripsi sebagaimana adanya tanpa diciptakan sebuah kesimpulan. Pengujian ini meliputi penyajian data dalam bentuk tabel dan memberikan hasil modus, mean, median serta rata-rata beserta standar deviasi.

Tujuan dalam menelaah riset ini untuk mendeskripsikan variabel-variabel penelitian dengan mengeluarkan sebuah tabel berisi informasi angka maximum, minimum, rata-rata, standar deviasi dan juga jumlah data yang diolah tanpa dilakukannya uji hipotesis (Ghozali, 2011)

\section{Analisis Regresi Data Panel}

Menurut Basuki dan Prawoto (2017), penelitian yang memiliki data perusahaan banyak dan juga rentang waktu beberapa tahun disarankan menggunakan analisis regresi data panel. Kelebihan penggunaan metode ini adalah implikasi data bersifat informatif dan bervariasi sehingga mengurangi kolinieritas.

Kesulitan yang ditemukan pada model penelitian merupakan adanya potensi adanya gangguan yang disebabkan oleh penggunaan metode observasi runtut waktu dan metode antar ruang. Pemanfaatan observasi antar ruang berpotensi timbul ketidak konsistenan akibat skala yang berbeda juga observasi runtut waktu yang dapat menyebabkan autokorelasi antar observasi (Nurlita. 2018).

\section{Uji Hipotesis}

Untuk memperoleh jawaban dari perumusan masalah yang diuraikan pada bab I dibutuhkan uji hipotesis yang pantas terkait hipotesis yang dirumuskan. Adapun pengujian meliputi Uji F serta Uji t.

Pengujian dengan Uji F bermaksud untuk mengetes data yang telah dikumpulkan sebelumnya secara simultan 
atau keseluruhan sekaligus. Sedangkan uji t bermaksud untuk menciptakan hasil pengujian secata parsial atau diberikan sebuah tabel dengan signfikansi setiap variabel.
4 ANALISIS DAN PEMBAHASAN

Hasil pemilihan sampel tersebut telah dirincikan pada table dibawah sebagai berikut:

Tabel 4.1 Hasil Penelitian Sampel

\begin{tabular}{lr}
\hline \multicolumn{1}{c}{ Keterangan } & Jumlah \\
\hline Perusahaan yang terdaftar di BEI 2014 -2018 & 629 perusahaan \\
Perusahaan dengan data yang tidak lengkap & 498 perusahaan \\
Perusahaan yang dijadikan sampel & 131 perusahaan \\
Tahun penelitian & 5 tahun \\
Jumlah data sampel & 655 data \\
Jumlah data yang diuji & 655 data \\
\hline
\end{tabular}

Sumber: Data sekunder diolah (2020)

Variabel yang terpilih sebagai beberapa variabel penelitian adalah kepemilikan manajerial, institusional, kebijakan hutang dan CSR sebagai variabel independen. Penelitian ini menggunakan kebijakan dividen sebagai variabel dependen dan dengan menambahkan ukuran perusahaan sebagai variabel kontrol. Pengujian pertama yang dilakukan adalah pengujian statistic deskriptif dimana table akan berisikan serta merincikan angka minimum, maximum, rata-rata dan standar deviasi sebuah kumpulan data untuk melihat data mana yang memiliki angka terbesar, terkecil, rata-rata dari keseluruhan data dan standar deviasi. Hasil Statistik Deskriptif data pada penelitian kali ini telah disajikan dalam tabel dibawah sebagai berikut:

Tabel 4.2 Hasil Uji Statistik Deskriptif

\begin{tabular}{|c|c|c|c|c|c|}
\hline & & Minimum & Maximum & Mean & Std. Deviation \\
\hline Kebijakan Dividen & 655 & 0.0169 & 0.8929 & 0.3886 & 0.4139 \\
\hline Kepemilikan & 655 & 0,0569 & 0.9932 & 0.7019 & 0.1606 \\
\hline Manajerial & & & & & \\
\hline Kepemilikan & 655 & 0.0424 & 0.9877 & 0.7032 & 0.1541 \\
\hline Institusional & & & & & \\
\hline Kebijakan Hutang & 655 & 0,0101 & 1,6912 & 0,3403 & 0,4292 \\
\hline $\begin{array}{l}\text { Corporate Social } \\
\text { Responsibility }\end{array}$ & 655 & 0,0333 & 0.813 & 0.3628 & 0.2037 \\
\hline $\begin{array}{l}\text { Ukuran Perusahaan } \\
\text { (Milyar) }\end{array}$ & 655 & 133,782 & 1.126 .248 & 41.268 & 133.416 \\
\hline Valid N & 655 & & & & \\
\hline
\end{tabular}

Sumber: Data sekunder diolah (2020)

Hasil dapat dilihat pada tabel 4.2 dimana tertera variabel dependen dan independen yang

memiliki $\mathrm{N}$ sebanyak 655 data yang diteliti. Selain kolom $\mathrm{N}$ adanya kolom untuk melihat hasil nilai terkecil, terbesar, rata-rata dan standar deviasi.

Pada variabel kebijakan dividen terlihat bahwa data memiliki nilai minimum 0,0169 dan nilai maksimum sebesar 0,8929. Variabel ini juga memiliki rata-rata sebesar 0,3886 dan standar deviasi sebesar 0,4139. Nilai maksimum berdasarkan data yang telah diambil dari laporan keuangan BEI bahwa pembayaran dividen terbesar diantara seluruh data yang telah diolah dimiliki oleh perusahaan Plaza Indonesia Realty Tbk dengan kode saham PLIN pada tahun 2014 dan perusahaan dengan nilai minimum adalah Indomobil Sukses Internasional Tbk tahun 2016 yang 
artinya perusahaan tersebut pada tahun tersebut terdapat penurunan laba sehingga berkurangnya angka pembagian dividen (Febrina, 2019).

Nilai terendah pada variabel kepemilikan manajerial adalah 0.0569 yang artinya kepemilikan saham oleh pihak manajerial dalam perusahaan tersebut sedikit. Nilai maksimum adalah sebesar 0,9932 yang dimana apabila kepemilikan manajerial tinggi maka seorang manajer akan ada kelakuan oportunistik untuk mendapatkan dividen yang tinggi (Kartika, 2019). Rata-rata pada variabel ini menunjukkan angka 0,7019 dan standar deviasi sebesar 0,1606.

Pada hasil uji data kepemilikan institusional menunjukkan angka tertinggi sebesar 0,9877 yang menunjukkan saham perusahaan tersebut dimiliki oleh pihak pemegang saham diluar pihak manajemen perusahaan atau lembaga non-bank. Angka minimum menunjukkan sebesar 0,0424 dimana artinya saham perusahaan tersebut tidak didominasi oleh pihak institusional. Hasil uji data juga menunjukkan rata-rata sebesar 0,7032 dalam arti kebanyakan perusahaan memiliki kepemilikan saham institusional yang tinggi dan standar deviasi sebesar 0,1541 .

Hasil pengujian kebijakan hutang memberikan hasil nilai minimum sebesar 0,0101 dan nilai maksimum sebesar 1,6912. Adapula rata-rata nya sebesar 0,3403 dan standar deviasi 0,4292. Perusahaan dengan hutang terendah dimiliki oleh Nippon Indosari Corpindo pada tahun 2014 dimana perusahaan tersebut tidak banyak meminjam dana dari pihak ketiga agar mengurangi resiko pelunasan hutang di masa yang akan datang. Nilai kebijakan hutang tertinggi dimiliki oleh FKS Multi Agro pada tahun 2018 yang berarti perusahaan tersebut memerlukan dana untuk melakukan kegiatan operasional perusahaan sehingga meminjamkan dana dari pihak ketiga ini dapat mengakibatkan penurunan pembayaran dividen dikarenakan keuntungan disisihkan untuk pelunasan hutang (Sofia, 2016).

Hasil uji data corporate social responsibility menunjukkan angka 0,0333 dan angka tertinggi 0,8134. Ini menunjukkan ada beberapa perusahaan yang telah taat dan bertanggung jawab terhadap lingkungan, angka tertinggi dimiliki oleh perusahaan Indofood Sukses Makmur pada tahun 2016 dan PT Timah Tbk tahun 2015 dalam arti mereka bertanggung jawab sosial dan lingkungan sehingga nama mereka akan membaik dan menarik minat para investor untuk berinvestasi ke 2 (dua) perusahaan tersebut (Ira \& Titi, 2014). Angka corporate social responsibility rendah dimiliki oleh perusahaan Total Bangun Persada Tbk dimana mereka masih kurang melaksanakan CSR dalam kegiatan operasional mereka sehingga investor cenderung kurang berminat.

Pada hasil pengujian mengenai ukuran perusahaan didapatkan hasil angka tertinggi yaitu sebesar 1.126.248 dan angka terkecil sebesar 133,782. Angka terbesar tersebut dimiliki oleh perusahaan bernama PT Bank Rakyat Indonesia pada tahun 2018 ini menunjukkan bahwa perusahaan tersebut memiliki ukuran besar dan aktivitas operasional perusahaan tersebut sangat tinggi dikarenakan ukuran perusahaan yang relative besar (Pradhana et al., 2014). Perusahaan yang besar diharapkan memiliki kapasitas dalam membayar dividen disbanding perusahaan kecil (Chang \& Rhee, 1990). Hasil pengujian juga membuahkan hasil rata-rata sebesar 41.268 dan standar deviasi yang menunjukkan angka 133.416.

\section{Pemilihan Model Terbaik}

Seleksi ini didefinsiikan sebagai pemilihan yang disesuaikan berdasarkan hasil pengolahan data antar 2 (dua) model dinamakan Pooled Least Square (PLS) atau Fixed Effect Mode (FEMl. Dengan memperhatikan output pada kolom probabilitas apabila angka berada di atas 
atau melebihi batas 0.05 akan digunakan model PLS dan tidak mencapai 0.05 maka FEM merupakan model terbaik.

Apabila FEM merupakan model yang terbaik maka wajib diteruskan dengan 2 (dua) pengujian. Pengujian selanjutnya merupakan Uji Chow dan Uji Hausman sebagai salah satu pengolahan data dalam pemilihan model sesuai.

\section{Hasil Uji Chow}

Dengan memperhatikan nilai prob. dimana apabila hasil probabilitas melebihi 0.05 maka model terbaik adalah Pooled Least Square dan apabila sebaliknya maka gunakan Fixed Effect Model yang dilanjutkan dengan uji Hausman.

Tabel 4.3 Hasil Uji Chow

\begin{tabular}{lrr}
\hline Effects Test & Prob. Kesimpulan \\
\hline Cross-section & \multicolumn{2}{r}{ Fixed Effect } \\
Chi-square & 0.0000 & Model \\
\hline
\end{tabular}

Sumber: Data sekunder diolah (2020) Nilai probabilitas pada table nilai prob. (p-value) $<0.05$, maka terpilih model terbaik yakni Fixed Effect Model (FEM) dan harus dilanjutkan dengan uji Hausman.

\section{Hasil Uji Hausman}

Pemilihan model terbaik antara Fixed Effect Model dan Random effect model dapat ditentukan dengan melakukan uji Hasuman. Hasil memperlihatkan 0,062 yang melebihi batas Fixed Effect Model sehingga dapat model terbaik adalah dengan menggunakan model Random Effect.
Tabel 4.4 Hasil Uji Hausman

\begin{tabular}{lcc}
\hline $\begin{array}{l}\text { Test } \\
\text { Summar } \\
\mathbf{y}\end{array}$ & Prob. & $\begin{array}{c}\text { Kesimpu } \\
\text { lan }\end{array}$ \\
\hline $\begin{array}{l}\text { Cross- } \\
\text { section } \\
\text { random }\end{array}$ & 0.0672 & $\begin{array}{c}\text { Random } \\
\text { Effect }\end{array}$ \\
\hline
\end{tabular}

Sumber: Data sekunder diolah (2020)

\section{Hasil Uji Hipotesis \\ Hasil Uji F}

Tabel 4.5 Hasil Uji F-Fixed Effect Model

\begin{tabular}{lcc}
\hline $\begin{array}{l}\text { Cross Section } \\
\text { Fixed }\end{array}$ & Sig. & Kesimpulan \\
\hline $\begin{array}{l}\text { Prob }(F- \\
\text { statistic })\end{array}$ & 0.0000 & Signifikan \\
\hline
\end{tabular}

Sumber: Data sekunder diolah (2020)

Dengan melihat hasil nilai Prob. (Fstatistic) apabila hasil berada di atas 0.05 maka variabel tersebut dianggap tidak memiliki signifikansi terhadap variabel independen dan apabila berada dibawah 0.05 maka adanya keterkaitan antara kedua variabel tersebut. Hasil pengujian uji $\mathrm{F}$ menunjukkan angka 0.0000 maka dari seluruh variabel yang diteliti secara simultan bersignifikan terhadap dependen

\section{Hasil Uji t}

Pengujian keterkaitan antar variabel secara parsial sama seperti uji $F$ apabila hasil menunjukkan angka di atas 0.05 maka tidak adanya pengaruh signifikan antara variabel independen tersebut terhadap dependen dan sebaliknya.

Tabel 4.6 Hasil Uji $t$

\begin{tabular}{lccl}
\hline \multicolumn{1}{c}{ Variabel } & Coefficient & Prob. & Hasil \\
\hline (Constant) & 3,246494 & 0,0780 & \\
Kepemilikan Manajerial & 0,131246 & 0,0495 & Signifikan Positif \\
Kepemilikan Institusional & 0,162310 & 0,0217 & Signifikan Positif
\end{tabular}




\begin{tabular}{lccc} 
Kebijakan Hutang & 0,024422 & 0,0223 & Signifikan Positif \\
$\begin{array}{l}\text { Corporate Social } \\
\text { Responsibility }\end{array}$ & 0,109388 & 0,3723 & Tidak Signifikan \\
Ukuran Perusahaan & $-0,245026$ & 0,0417 & Signifikan Negatif \\
\hline
\end{tabular}

Sumber: Data sekunder diolah (2020)

\section{Pembahasan Hasil Pengujian $\mathrm{H}_{1}$}

Kepemilikan manajerial tinggi dapat menyebabkan dividen payout menjadi sedikit dikarenakan manajer selalu berharap investasi di periode seterusnya akan ditutup dari sumber internal. Pribadi (2012) berpendapat bahwa apabila manajer pada suatu perusahaan memiliki proporsi saham yang kecil maka perusahaan cenderung membagikan hak pemegang saham secara tinggi dan sebaliknya jika pembayaran dividen menurun diakibatkan oleh tingginya kepemilikan saham oleh manajer dalam suatu perseroan. Analisis yang dilakukan oleh Nuringsih (2005) menyatakan bahwa adanya keterlibatan seorang manajer dalam kepemilikin manajerial maka akan menyebabkan asset yang dimiliki tidak optimal dan manajer berharap dividen yang cenderung lebih besar

Variabel ini menunjukkan hasil koefisien regresi 0.131246 dan karena nilai probabilitas berkisar dibawah 0.05 yaitu 0.0495 maka variabel ini bersignifikan. Hasil penelitian memiliki hasil yang didukung oleh penelitian yang dilakukan oleh Rais (2017) dan Devi (2014) dimana tidak ditemukannya adanya signifikansi antara kepemilikan manajerial dengan keputusan pembayaran dividen. Hal ini malah tidak sejalan dengan penelitian yang dilaksanakan oleh Fauzi dan Mursallam (2015), Indriani (2015), Yulianto (2011) dan Wirdani (2019) yang hasil penelitian menyatakan tidak ditemukan adanya pengaruh antar kedua variabel.

\section{Pembahasan Hasil Pengujian $\mathrm{H}_{2}$}

Dalam terminologi Bursa Saham, kepemilikan institusional didefinisikan sebagai saham yang dimiliki oleh lembaga keuangan bukan bank contohnya seperti lembaga reksa dana, dana pension, asuransi dan investasi. Hanafi (2005) berpendapat bahwa tingginya pemilik saham institusional maka semakin tinggi pengawasan dari luar dan juga mengurangi agency cost. Kesamaan hasil oleh Nasir (2008) dimana disebutkan bahwa naiknya kepemilikan oleh institutional maka berkurangnya kos agen dan perusahaan akan membagikan cenderung rendah.

Variabel kepemilikan institusional menghasilnya nilai koefisien sebesar 0.162310 dan nilai probabilitas signifikan sebesar 0.0217. Maka, adanya signifikansi antar variabel. Kesimpulan ini berhubungan dengan penelitian yang dilaksanakan oleh Dewi (2012) dimana disimpulkan bahwa kepemilikan institusional memiliki signifikansi pada kebijakan dividen dimana hasil ini terdukung dengan penelitian yang dilaksanakna oleh Kurniawati et al., (2015), (Nisa, 2016) dan Sutanto, Marciano, \& Ernawati (2017) yang menghasilkan pernyataan bahwa ditemukannya pengaruh pada kepemilikan institusional pada kebijakan dividen. Kesimpulan ini tidak sejalan dan tidak didukung oleh penelitian yang dilaksanakan oleh Dewi (2012), Wikansari (2015) dan Jayanti \& Puspitasari (2019) yang menerima hasil bahwa tidak ditemukannya pengaruh bersignifikan terhadap kebijakan dividen.

\section{Pembahasan Hasil Pengujian $\mathbf{H}_{3}$}

Kebijakan hutang pada dasarnya merupakan keputusan peminjaman dana sebagai pendanaan kegiatan operasional perusahaan. Pendayagunaan hutang tinggi 
dapat mengakibatkan penurunan dividen dikarenakan pendapatan yang telah diterima akan digunakan kembali sebagai pelunasan hutang (Saerang, 2015). Sebaliknya apabila penggunaan hutang rendah maka keuntungan yang di dapatkan dapat dialokasikan untuk kesejahteraan para pemegang saham.

Variabel kebijakan hutang atau debt earning ratio (DER) menunjukan bahwa nilai koefisien regresi sebesar 0.24422 dan nilai probabilitas signifikan sebesar 0.0223. Dengan diketahui nominal tersebut maka dapat dijelaskna variabel debt earning ratio atau kebijakan hutang bersignifikan pada kebijakan pembayaran dividen.

Berdasarkan hasil penelitian kebijakan hutang yang diukur dengan DER. Jikalau perusahaan memiliki hutang tinggi akibatnya resiko perusahaan juga tinggi karena perusahaan harus membagi pendapatan perusahaan agar dijadikan sebagai cadangan pembayaran hutang tersebut. Oleh sebab itu, apabila sebuah perusahaan menaikkan pembayaran dividen maka akan berpengaruh terhadap pendanaan operasional perusahaan. Argumen ini diperkuat oleh Indahningrum \& Ratih (2009) ), Isticharoh (2016), Thaib \& Taroreh (2015) yang menyatakan bahwa ditemukannya pengaruh signifikan antara kebijakan hutang pada kebijakan dividen. Hal ini bertentangan dengan penelitian yang dilaksanakan oleh Setiawati \& Yesisca (2016) , Sulis (2018) yang mendapatkan kesimpulan bahwa kedua variabel tersebut tidak memiliki signfikansi apapun

\section{Pembahasan Hasil Pengujian $\mathrm{H}_{\mathbf{4}}$}

$C S R$ adalah tanggung jawab yang wajib dilakukan oleh seluruh badan usaha sebagai pertanggung jawaban mereka dalam meningkatkan kualitas hidup dan mencegah kerusakan yang terjadi akibat kegiatan perusahaan. Dengan melakukan CSR maka nama perusahaan akan membaik di kalangan masyarakat ini juga mempengaruhi minat investor. Kebanyakan investor cenderung berminat berinvestasi kepada entitas yang melaksanakan dan mengungkapkan informasi kegiatan CSR

$$
\text { Variabel corporate social }
$$

responsibility menunjukan nilai probabilitas signifikan sebesar 0.3723 sehingga tidak ada signifikansi. Hal ini menunjukkan bahwa dengan adanya peningkatan nilai pada corporate social responsibility maka tidak akan ada pengaruh dengan kebijakan pembayaran dividen. Hasil yang sama pada penelitian Ira (2014) dan Titi (2014) yang menyatakan tidak adanya pengaruh yang signifikan pada kebijakan dividen akan tetapi penelitian yanh dilaksanakan oleh Armi (2016) yang hasilnya tidak sejalan dimana dinyatakan bahwa CSR adanya pengaruh yang signifikan pada kebijakan pembayaran dividen.

\section{Uji Goodness of Fit Model}

Pengujian menunjukkan persentase seberapa banyak sebuah variabel menjelaskan variabel dependen. Persentase tersebut dapat diambil dengan melihat nominal pada kolom Adjusted $R$ squared.

Output Uji Goodness of Fit Model memperlihatkan angka 0,372394 atau $37,24 \%$. Persentase ini menghasilkan kesimpulan bahwa sebesar $37,24 \%$ variabel independen dapat menjelaskan variabel dependen, sisa dari persentase diartikan sebagai variabel lain yang tidak dipilih sebagai variabel dan tidak diteliti pada studi ini.

Tabel 4.7

Uji Goodness of Fit Model

\begin{tabular}{lcc}
\hline $\begin{array}{l}\text { Variabel } \\
\text { Dependen }\end{array}$ & R Square & $\begin{array}{c}\text { Adjusted } \\
\mathbf{R} \\
\text { Squared }\end{array}$ \\
\hline $\begin{array}{l}\text { Kebijakan } \\
\text { Dividen }\end{array}$ & 0.505043 & 0.372394 \\
\hline
\end{tabular}

Sumber: Data sekunder diolah (2020) 


\section{KESIMPULAN DAN SARAN}

Berdasarkan hasil-hasil penelitian yang telah diuraikan di bab sebelumya dapat dijelaskan pada kesimpulan ini. Penelitian ini telah menentukan sebanyak 131 perusahaan yang telah memenuhi kriteria selama tahun 2014-2018 dengan bantuan pengujian melalui 2 (dua) perangkat lunak SPSS 22 dan Eviews10. Hasil penelitian pada variabel kepemilikan manajerial menggambarkan bahwa variabel tersebut ada hubungan terhadap kebijakan dividen dimana apabila kepemilikan manjerial tinggi maka nominal pembayaran akan menurun sebaliknya jika kepemilikan manajerial rendah maka nominal pembayaran dividen akan meningkat. Hasil penelitian pada variable kepemilikan institusional bahwa variabel tersebut memiliki hubungan terhadap dependen. Pengaruh antara kedua variabel adalah apabila kepemilikan institusional tinggi maka akan adanya pengawasan intensif yang mengakibatkan berkurangnya sifat opportunistic seorang manajer sehingga pembayaran dividen akan meningkat.

Hasil penelitian pada variabel kebijakan hutang menggambarkan bahwa variable tersebut memiliki signifikansi pada kebijakan dividen dikarenakan semakin tinggi hutang dalam suatu perusahaan akan mengurangi pembayaran dividen dikarenakan pendapatan akan dijadikan sebagai cadangan dana untuk melunasi hutang-hutang tersebut. Hasil penelitian pada variable corporate social responsibility menggambarkan bahwa variable tersebut tidak adanya signifikansi pada kebijakan dividen maka dapat diambil kesimpulan bahwa tidak ditemukannya hubungan antara corporate social responsibility dengan kebijakan dividen. Hasil penelitian pada variable ukuran perusahaan menggambarkan bahwa variable tersebut memiliki signifikan negatif terhadap kebijakan dividen karena ukuran perusahaan tidak menjadi penentu dalam kebijakan pembayaran dividen dikarenakan investor cenderung lebih tertarik dan tentu akan memilih perusahaan yang memiliki kinerja baik dibandingkan dengan perusahaan berukuran besar.

\section{Keterbatasan}

Selama proses pelaksanaan studi ini ditemukan beberapa keterbatasan yang tidak dapat di hindari. Salah satu keterbatasan yang ditemukan selama studi yakni pengambilan sampel data yang tidak luas dimana hanya memilih perusahaan yang tercantum pada website BEI.

Beberapa keterbatasan lain merupakan kelengkapan laporan keuangan pada website tersebut dimana beberapa perusahaan tidak memiliki atau tidak ditemukannya laporan tahunan yang lengkap walaupun telah terdaftar di BEI. Adapula keterbatasan lain yang diketahui setelah melakukan pengujian goodness of fit dimana hasil menunjukkan hanya ada $37.24 \%$ pengaruh dari variabel yang diteliti sekarang sehingga adanya variabel lain yang diduga berpengaruh.

\section{Rekomendasi}

Beberapa rekomendasi yang dapat diberikan untuk studi tahap selanjutnya agar lebih berkembang adalah dengan meneliti sampel dari negara lain yang masih jarang diteliti di Indonesia. Dalam penelitian berikutnya dapat pula menambah beberapa variabel baru yang diprediksi memiliki kaitan dengan kebijakan dividen seperti kepemilikan individual, pemerintah ataupun keluarga. 
Bagi studi selanjutnya, diharapkan pula dapat menambah tahun pengamatan dikarenakan tidak seluruh perusahaan yang terdaftar membayarkan dividen per tahun. Kepada peneliti selanjutnya dikarenakan terdapat hasil penelitian yang tidak sesuai pada teori awal, maka alangkah baiknya mencari berbagai teori alternatif dan referensi mengenai faktor yang benarbenar mempengaruhi kebijakan dividen.

\section{DAFTAR PUSTAKA}

Adesola, W. A., \& Okwong, A. E. (2015). An Empirical Study of Dividend Policy of Quoted Companies in Nigeria.

https://doi.org/10.4314/gjss.v8i1.489 $\underline{07}$

Aditya, H. (2013). Kajian Pustaka, Kerangka Pemikiran dan Hipotesis. https://doi.org/10.1017/CBO9781107 $\underline{415324.004}$

Affifah, O. G., Ratih, A. E., \& Husna, A. (2018). Pengaruh Kepemilikan Manajerial, Kepemlikan Institutional, Kebijakan Hutang, Ukuran Perusahaan Terhadap Kebijakan Deviden Pada Perusahaan Manufaktur yang Terdapat di Bursa Efek Indonesia. 1-17.

Al-kuwari, D. (2009). Determinants of the Dividend Policy in Emerging Stock Exchanges: The Case of GCC Countries, 2(2), 38-63.

Ali, N. Y., Mohamad, Z., \& Baharuddin, N. S. (2018). The Impact of Ownership Structure on Dividend Policy: Evidence of Malaysian Listed Firms, 4(10), 35-44.
Al-najjar, B. (2014). Dividend behaviour and smoothing new evidence from Jordanian panel data. https://doi.org/10.1108/10867370910 $\underline{974017}$

Al-nawaiseh, M. (2013). Dividend Policy and Ownership Structure: An Applied Study on Industrial Companies in Amman Stock Exchange. 5(2), 83-106. https://doi.org/10.5296/jmr.v5i2.2920

Ariefianto, M. D. (2012). Ekonometrika Esensi dan Aplikasi dengan Menggunakan EViews.

Aulia Rasyid, F., \& Sri Yuliandhari, W. (2018). Pengaruh Biaya Corporate Social Responsibility Dan Kebijakan Dividen Terhadap Nilai Perusahaan (Studi pada Perusahaan BUMN yang terdaftar di Bursa Efek Indonesia tahun 2012-2016). Jurnal Akuntansi Bisnis dan Ekonomi, 4(2), 11371148.

Basyarewan, U. N., \& Munawar, A. (2018). Analisis Kebijakan Dividen Terhadap Pertumbuhan Dan Harga Saham Perusahaan. (October 2014).

Bernice, Y. (2015). The Impact of Managerial Ownership, Institutional Ownership and Company Size Towards Debt Policy. IBEA International Conference on Business, Economics and Accounting, (April), 15-17.

Bhattacharyya, N., \& Elston, J. A. (2011). Dividends, Executive Compensation, and Agency Costs: Empirical Evidence from Germany University of Alaska-Anchorage, 11(1999), 1120.

Brighan, \& Houston. (2012). Dasar-dasar Manajemen Keuangan. 
Chen, J., \& Dhiensiri, N. (2009). Determinants of Dividend Policy: The Evidence from New Zealand. International Research Journal of Finance and Economics 34.

Dewi, I. A. P. P., \& Sedana, I. B. P. (2018). Faktor-Faktor Yang Mempengaruhi Kebijakan Dividen Pada Perusahaan Manufaktur Di Bursa Efek Indonesia. E-Jurnal Manajemen Universitas Udayana, 7(7), 3623.

https://doi.org/10.24843/ejmunud.20 18.v07.i07.p07

Dewi, R., \& Rusliati, E. (2017). Kepemilikan Institusional, Kepemilikan Manajerial, dan Ukuran Perusahaan Terhadap Kebijakan Dividen. Jurnal Riset Akuntansi Kontemporer, 11(1), 41-47.

Emzir. (2013). Metodologi penelitian pendidikan: Kuantitatif dan kualitatif.

Febrina, C. (2019). Pengaruh Corporate Social Responsibilitym Kebijakan Dividen, Struktur Modal dan Ukuran Perusahaan yang terdaftar di Bursa Efek Indonesia. 4, 5-10.

Fimanda, R., Raharjo, K., \& Oemar, A. (2015). Pengaruh Kepemilikan Manajerial, Kepemilikan Institusional. Kebijakan Hutang, Profitabilitas, Ukuran Perusahaan, dan Cash Position terhadap Kebijakan Dividen. Jurnal Universitas Pandanaran Semarang, 2(4), $1-20$. https://doi.org/10.13989/j.cnki.05176611.2015.10.011

Ghafur, F. (2019). Lunasi Utang, Hanson International Jual 49,99\% Saham Entitas Anak Usaha Artikel ini telah tayang di Investor.id dengan judul
"Lunasi Utang, Hanson International Jual 49,99\% Saham Entitas Anak Usaha" Penulis: Ghafur Fadillah Read more at: https://investor. Diambil dari https://investor.id/market-andcorporate/lunasi-utang-hansoninternational-jual-4999-sahamentitas-anak-usaha

Goleman, daniel; boyatzis, Richard; Mckee, A. (2019). Pengertian Hutang. Accounting and Finance, 53(9), 1689-1699. https://doi.org/10.1017/CBO9781107 415324.004

Halim. (2015). Kajian Pustaka, Kerangka Pemikiran Dan Hipotesis. (i), 16-45.

Ho, H. (2003). Dividend Policies in Australia and Japan, 91-100.

Indriani, W. (2015). Pengaruh Kepemilikan Manajerial Dan Kinerja Keuangan Terhadap Kebijakan Dividen Pada Perusahaan Manufaktur Yang Terdaftar Di Bursa Efek Indonesia Tahun 2012-2014 Wiwin Indriani R . Anastasia Endang S. 1-10.

Indriantoro, N., \& Supomo, B. (1999). Metodologi Penelitian Bisnis untuk Akuntansi dan Manajemen. (1).

Isticharoh, R. R. (2016). Pengaruh Kepemilikian Manajerial, kebijakan Hutang dan Profitabilitas Terhadap Kebijakan Dividen.Jurnal

Jain, R. (2007). Institutional and individual investor preferences for dividends and share repurchases. 59, 406-429. https://doi.org/10.1016/j.jeconbus. 20 07.04.004

Jarallah, S., \& Ullah, W. (2011). Evolving corporate governance and the dividends behavior regime in Japan. 
Centre for Financial \& Management

Studies.

Jayanti, I. S. D., \& Puspitasari, A. F. (2019). Ownership Structures and

Dividend Policy in Manufacturing Companies in Indonesia. TIJAB (The International Journal of Applied Business), $\quad 1(1), \quad 1$. https://doi.org/10.20473/tijab.v1.i1.2 $\underline{017.1-13}$

Kasmir. (2008). Bank dan Lembaga Keuangan Lainnya.

Lantz, C. E., \& Lions, C. (2016). Ownership structures effect on dividend policy.

Latifah, S. W. (2016). Tanggung Jawab Sosial Berdasarkan Iso 26000 Dan Nilai Perusahaan Yang Listed Di Bursa Efek Indonesia. Jurnal Ekonomika Bisnis, 03(01), 65-74. https://doi.org/10.22219/jekobisnis.v $3 \mathrm{i} 1.2230$

Liana, Lie. "Penggunaan MRA dengan Spss untuk Menguji Pengaruh Variabel Moderating terhadap Hubungan antara Variabel Independen dan Variabel Dependen." Dinamik, vol. 14, no. 2, 2009

Lukihardianti, A. (2019). BUMD Migas Hulu Kembali Berikan Deviden ke Pemprov Jabar. Diambil dari https://republika.co.id/berita/q3dcb33 68/bumd-migas-hulu-kembaliberikan-deviden-ke-pemprov-jabar

Machfoedz, M. (2007). Pengantar Bisnis Modern.

Nisa, H., Halim, E., \& H. (2016). Pengaruh Kepemilikan Institusional Dan Leverage Terhadap Kebijakan Dividen Dengan Free Cash Flow Sebagai Variabel Moderasi Pada Perusahaan Manufaktur Di Bei Periode 2011-2015. Jurnal Online
Mahasiswa Fakultas Ekonomi

Universitas Riau, 4(1), 387-401.

Nurarif, K. (2016). Metode Penelitian. https://doi.org/10.1017/CBO9781107 $\underline{415324.004}$

Nurwani. (2018). Pengaruh Kepemilikan Institusional, Kepemilikan Manajerial dan Profitabilitas Terhadap Kebijakan Dividen pada Perusahaan Manufaktur. E-Journal Economics, 3(1), 1141-1151. Diambil Wdari https://ejournal.unsrat.ac.id/index.ph p/emba/article/view/7928

Pujiati. (2015). Pengaruh Kepemilikan Manajerial, Kepemilikan Institusional, dan Kesempatan Investasi terhadap Kebijakan Dividen dengan Likuiditas sebagai Variabel Moderasi (Studi Empiris pada Perusahaan Sektor Industri Barang Konsumsi yang Terdaftar di Bursa Efek Indones. Artikel Ilmiah, 1-180.

Puspita, F. (2009). Analisis Faktor-Faktor Yang Mempengaruhi Kebijakan Dividend Payout Ratio.

Rachmad, A. N. (2013). Pengaruh struktur kepemilikan, leverage, dan return on asset terhadap kebijakan dividen. In Diponegoro Journal of Accounting (Vol. 2). Diambil dari http://ejournals1.undip.ac.id/index.php/accounting

Rais, B. N., \& Santoso, H. F. (2017). Pengaruh Kepemilikan Manajerial, Kepemilikan Institusional, Profitabilitas dan Ukuran Perusahaan Terhadap Kebijakan Deviden. Jurnal Ilmiah Manajemen Bisnis, 17(2), 111-124.

Ratna Damayanti, Fithri Setya Marwati, R. W. (2017). Analisa Kebijakan Dividen berdasarkan Teori Lintner. 
Jurnal Ekonomika Bisnis, 1(2), 183104. https://doi.org/10.22236/agregat Redding, L. S. (1995). Firm Size and Dividend Payouts, 248, 224-248.

S, A. (2016). Metodologi Penelitian: Pendekatan Penelitian. Artikel, 3340.

Saerang, I., \& Tommy, P. (2014). Kebijakan Hutang, Struktur Kepemilikan Dan Profitabilitas Terhadap Kebijakan Dividen Pada Perusahaan Food and Beverage Di Bursa Efek Indonesia. Jurnal Riset Ekonomi, Manajemen, Bisnis dan Akuntansi, 2(3), 817-830.

Setiawati, L. W., \& Yesisca, L. (2016).

Analisis Pengaruh Pertumbuhan Perusahaan, Kebijakan Utang, Collateralizable Assets, Dan Ukuran Perusahaan Terhadap Kebijakan Dividen Pada Perusahaan Manufaktur Yang Terdaftar Di Bursa Efek Indonesia Periode 2012-2014. Jurnal Akuntansi, 10(1), 52-82. https://doi.org/10.25170/jara.v10i1.4 $\underline{0}$

Setiawan, D., Bandi, B., Phua, L. K., \& Trinugroho, I. (2016). Ownership structure and dividend policy in Indonesia.

https://doi.org/10.1108/JABS-052015-0053

Setyowati, T. (2014). Pengaruh Profitabilitas, Kebijakan Dividen dan Corporate Social Responsibility terhadap Nilai Perusahaan.

Sugiarto, M. (2011). Pengaruh Struktur Kepemilikan dan Kebijakan Dividen terhadap Nilai Perusahaan dengan Kebijakan Hutang sebagai Intervening. Jurnal Akuntansi Kontemporer, 3(1), 243887.
Sugiyono. (2016). Faktor-faktor Dukungan Keluarga. 53(9), 1689-1699.

Sulis, E. (2018). Pengaruh Kepemilikan Manajerial, Kebijakan Hutang dan Kesempatan Investasi terhadap Kebijakan Dividen. 10(2), 1-15.

Sutanto, J., Marciano, D., \& Ernawati, E. (2017). Pengaruh Kepemilikan Institusional Terhadap Kebijakan Dividen Pada Perusahaan Sektor Industri Property, Real Estate, Dan Konstruksi Bangunan Yang Terdaftar Di Bei Periode 2011-2015. Jurnal Ilmiah Mahasiswa Universitas Surabaya, 6(2), 966-981.

Thaib, C., \& Taroreh, R. (2015). Pengaruh Kebijakan Hutang dan Profitabilitas Terhadap Kebijakan Dividen. Jurnal EMBA, 3(4), 215-225.

Utami, W. (2017). Implikasi Kebijakan Hutang, Kebijakan Dividen dan Kepemilikan Manajerial terhadap Nilai Perusahaan. Jurnal Akuntansi.

Vardaro, M. J., Systems, H. I. T., AG, H. T., Jari, A., Pentti, M., Information, B. G., ... Measurements, C. (2016). Pengaruh Profitabilitas dan Kebijakan Hutang terhadap Kebijakan Dividen Tunai, 2002(1), 35-40.

https://doi.org/10.1109/ciced.2018.85 92188

Wikansari, N. A. (2015). Pengaruh Profitabilitas, Struktur Kepemilikan, dan Investment Opportunity Set Terhadap Kebijakan Dividen Pada Perusahaan Manufaktur Yang Terdaftar di BEI. Acta Universitatis Agriculturae et Silviculturae Mendelianae Brunensis, 16(2), 3955.

https://doi.org/10.1377/hlthaff.2013.0 625 
Yuli, S. (2008). Kepemilikan Manajerial dan Institusional, Kebijakan Dividen, Ukuruan Perusahaan, Struktur Aktiva, dan Profitabilitas terhadap Kebijakan Hutang. Jurnal Keuangan dan Perbankan, 12(3), 384-398.

Zhang, Q., Zhang, L., Hongmei, Y., Luo, R., Rozelle, S., Brinton, C., ... Marchetti, A. (2018). Dividend Policies in Japan. World Development, $\quad 1(1), \quad 1-15$. https://doi.org/10.1016/j.worlddev.20 18.08.012 